\title{
Özel Eğitim ve Rehabilitasyon Merkezlerinde Çalışan Öğretmenlerin Mesleki Tükenmişlik Düzeyleri ve Yaşam Doyumlarının İncelenmesi
}

\author{
DOI: $10.26466 /$ opus.601008
}

\author{
Mehmet Yavuz \\ *Dr. Öğr. Üyesi Trakya Üniversitesi Eğitim Fakültesi Özel Eğitim Bölümü / Edirne / Türkiye \\ E-Posta: $\underline{\text { mehmetyavuz23@gmail.com }}$ \\ ORCID: $\underline{0000-0003-0762-1611}$
}

$\ddot{O} z$

Bu araştırmada Özel Eğitim ve Rehabilitasyon merkezlerinde (ÖERM) çalışan öğretmenlerin mesleki tükenmişlik ile yaşama doyum düzeyleri çeşitli değişkenler açısından incelenmesi ve mesleki tükenmişlik ile yaşama doyum arasındaki ilişkiyi incelemeyi amaçlanmıştır. Araştırmada genel tarama modeli kullanılmıştır. Araştırmaya Edirne ve İstanbul illerinde toplam 175 öğretmen katılmıştır. Araştırmada verilerin toplanması için Kaner, Şekercioğlu ve Yellice (2008) tarafindan geliştirilmiş Öğretmen Mesleki Tükenmişlik ölçeği ve Diener, Emmons, Larsen ve Griffin (1985) tarafindan geliştirilmiş, Dă̆ll ve Baysal (2016) tarafindan Türkçeye uyarlanan yaşam doyumu ölçeği kullanilmıştır. Verilerin analizi için T-Testi ve Pearson Korelasyon analizi uygulanmıştır. Araştırma sonuçlarına göre ÖERM'lerde çalışan öğretmenlerin mesleki tükenmişlik düzeyleri yüksek olduğu gözlenmiştir. Öğretmenlerin mesleki tükenmişlik düzeyleri cinsiyet desiğkeni açısından, kadın öğretmenlerin, is arkadaşlarında destek görenlerin ve yöneticlerden destek gören öğretmenlerde

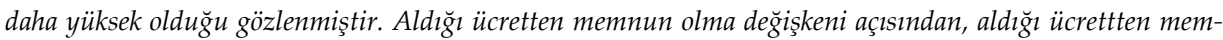
nun olan ve olmayan öğretmenlerin mesleki tükenmişlik düzeylerinde bir fark gözlenmemiştir. Ancak fiziksel ve duygusal tükenmişlik alt boyutunda aldığı ücretten memnun olan öğretmenlerin mesleki tükenmişlik dzüeylerinin daha yüksek olduğu gözlenmiştir. Öğretmenlerin yaşam doyum düzeylerinin orta düzeyde olduğu gözlenmiştir. Öğretmenlerin yaşam doyum düzeyleri cinsiyet değişkeni açısından kadın öğretmenlerden yana, aldığı ücretten memnun olan öğretmenlerden yana, iş arkadaşlarından destek gören öğretmenlerde daha yüksek düzeyde gözlenmiştir. Özel Eğitim ve Rehabilitasyon merkezlerinde (ÖERM) çalışan öğretmenlerin mesleki tükenmişlik düzeyleri ile yaşam doyumları arasında negatif yönlü ilişki gözlenmiştir.

Anahtar Kelimeler: Özel Eğitim, Mesleki Tükenmişlik, Yaşam Doyumu 


\title{
An Investigation on Occupational Burnout Levels and Life Satisfaction of Teachers Working in Special Education and Rehabilitation Centers
}

\begin{abstract}
The aim of this study is to investigate the levels of occupational burnout and life satisfaction of teachers working in Special Education and Rehabilitation Centers (SERCs) in terms of various variables and to investigate the relationship between occupational burnout and life satisfaction. In the research, general survey model was used and a total of 175 people working in Edirne and Istanbul participated in the study. In order to collect the data, the occupational burnout scale for teachers developed by Kaner, Şekercioğlu and Yellice (2008) and the satisfaction with life scale which was originally developed by Diener, Emmons, Larsen and Griffin (1985) and was later adapted to Turkish by Dağh and Baysal (2016) were used. In addition to SPSS 22.0 software, T-Test and Pearson Correlation analysis were used to analyze the data. According to the results of the study, the occupational burnout level of teachers working at SERCS was high. Concerning the gender variable, significant differences were found in favor of female teachers, those who were supported by their colleagues, and those who were supported by their administrators. Although no significant difference was detected regarding the variable about being satisfied with the salary, significant differences were detected in favor of the ones who are satisfied with their salary in the sub-dimension of physical and emotional burnout. Teachers' life satisfaction level was found to be moderate. A significant difference was detected in favor of the female teachers, the teachers who were satisfied with the salary they received, and those who were supported by their colleagues in the gender variable. A negative correlation was found between occupational burnout levels and life satisfaction.
\end{abstract}

Keywords: Special Education, Professional Burnout, Life Satisfaction, 


\section{Giriş}

Tükenmişlik ilk olarak Freudenberger (1974) tarafından "başarısızlık, yıpranma, enerji ve güç kaybı veya insanın iç kaynakları üzerinde karşılanamayan istekler sonucunda ortaya çıkan bir tükenme durumu" olarak tanımlanmıştır. Daha sonra Maslach ve Jackson (1981), tükenmişliği; insanlarda oluşan fiziksel bitkinlik, uzun süreli yorgunluk, çaresizlik ve umutsuzluk duygularıyla birlikte kişinin çalıştı̆̆ işe, yaşama ve diğer bireylere yönelik sergilediği olumsuz tutumlarından oluşan fiziksel ve zihinsel boyutlu bir sendrom olarak tanımlamıştır. Tükenmişlik sendromu genellikle insanlarla yüz yüze çalışmak zorunda olan bireylerde görülmektedir (Tuğrul ve Çelik, 2002). Tükenmişlik sendromu genel olarak üç alt boyuttan oluşmaktadır. Bu boyutlar duygusal tükenme, duyarsızlaşma ve kişisel başarının azalmasıdır (Maslach, 1993).

\section{Duygusal Tükenme}

Duygusal tükenme, bireyin duygusal kaynağının/enerjisinin tükendiğini hissetmesidir. Bu durum çalışan bireyin harcadığı emekle mesleki memnuniyet arasındaki dengede sorun olduğunda ortaya çıkan bir durumdur (Jackson, Schwab ve Schuler, 1986). Mesleki yönden tükenmişlik yaşayan bireylerde yorulmuşluk hissi, düşük enerji, duyguların yıpranması durumları görülmektedir (Akın ve Oğuz, 2010). Çalışan birey bu dengede bir sorun olduğunu hissettiğinde tükenmişlik sendromu ortaya çıkmaktadır (Jackson, Schwab ve Schuler, 1986; Tümkaya, 1996).

\section{Duyarsızlaşma}

Duyarsızlaşma Tümkaya'ya (1996) göre çalışan bireylerin insanlara bir nesneymiş gibi davranmalarıdır. Schwarzer, Schmitz ve Tang (2000) göre duyarsızlaşma; olumsuzluk, aşırı sinirliolma durumu, bir hedefinin olmaması durumu, kişiler arası kötü ilişkiler olarak tanımlanmaktadır. Duyarsızlaşan bireyler hizmet alan kişilere karşı duygusuz, ilgisiz ve olumsuz davranmaktadırlar. Garden'na (1987) göre duyarsızlaşma başka insanlara ilgi göstermeyi, onlardan uzaklaşmayı ve aldırış etmemeyi 
içerir. Dolayısıyla duyarsızlaşma özetle bireyin hem kendini hemde hizmet verdiği kişileri insancıl olmayan şekilde davranmasıdır.

\section{Düşük Kişisel Başarı}

Bir anlamda bireyin öz-değerlendirmesi sonucunda mesleğinde kendini yetersiz hissetmesidir (Schwarzer, Schmitz ve Tang, 2000). Bireyin tüm gayretlerine rağmen yaptığı işte iyi sonuçlar alamaması durumudur (Tümkaya, 1996). Kendini mesleki anlamda yetersiz hisseden bireyler kendilerini eksik olarak algılarlar, mesleğinde yetkin olmadığını düşünürler ve motivasyonları düşer. Bundan dolayı karamsarlık yaşarlar ve yaptığı işte gayretinin yeterli olmadığını düşünürler (Maslach, Schaufeli ve Leiter, 2001).

Özel Eğitim ve Rehabilitasyon merkezlerinde (ÖERM) çalışan öğretmenlerde tükenmişlik sendromunun görülmesi muhtemeldir (Akıncı, 2016). Çünkü buralarda çalışan öğretmenler yetersizliği olan bireylerle çalışmaktadırlar. Yetersizliği olan bireylerin, gelişim gerilikleri, öğretimin zor olması ve öğretmenin mesleki doyum elde edememesi gibi faktörlerden dolayı özel eğitim alanında çalışan öğretmenlerde tükenmişlik sendromu görülebilmektedir (Sucuoğlu ve Kuloğlu, 1996). Ayrıca ÖERM'lerde çalışan öğretmenler; yetrsizliği olan çocukların ailelerinin bilinçli olmaması sebebiyle hem kendi çocuklarından hemde öğretmenlerden beklentilerini yüksek veya düşük tutabilmektedirler, bu kurumları denetleyen müfettişlerin özel eğitimci olmamasının, tatillerin uzun olması sebebiyle öğrencilerin tatile gittiğinde kazanmış olduğu davranışları unutarak gelmelerinin, sınıfların homojen dağılmamasının genel sorunlar arasında olduğunu belirtmişlerdir (Karasu ve Mutlu, 2014). Öğretmenler ÖERM'lerde çok yoğun (günde sekiz saat) çalışması, düşük ücret almaları, evrak işlerinin fazla olması, eğitim materyali sıkıntısı yaşamaları ve kurumların fiziki şartlarının kötü olduğunu ifade etmişlerdir (Ufuk, 2019). Bunların yanında öğretmenler yöneticilerle problem (Çetin ve Şen, 2017; Hocalar, 2018; Ufuk, 2019), velilerle problemler yaşayabilmektedirler (Çetin ve Şen, 2017; Ufuk, 2019).

ÖERM'lerdeki bu problemlere paralel olarak Akman (2017) yaptığ araştırmada ÖERM'lerde çalışan öğretmenlerin, iş doyum düzeylerini "İşimle ilgili Kararsızım" düzeyinde, iş doyum ölçeğinin alt faktörü olan 
dışsal etken boyutunda ise "İşimle İlgili Kararsızım" düzeyinde olduğu sonucuna ulaşmıştır. Selbi (2018) ise yaptığı araştırmada ÖERM'lerde çalışan öğretmenlerde depresyon düzeylerini yüksek bulmuştur. Ayrıca bu merkezlerinde çalışan fizyoterapistlerin yaşam kalitesini öğretmenlerden daha düşük olarak gözlemlemiştir. Akıncı (2016) ise yaptığı araştırmada ÖERM'lerde çalışan öğretmenlerin tükenmişlik düzeylerinin devlet kurumlarında çalışan özel eğitim çalışanlarına oranla daha yüksek olduğu sonucuna ulaşmıştır.

Tükenmişliğe etki eden farklı değişkenler bulunmaktadır. Yaşam doyumu bu değişkenlerden biridir (Avşaroğlu, Deniz ve Kahraman, 2005). Yaşam doyumu, bireyin kendi yaşamının niteliğini bütüncül bir çerçevede ve içsel bir şekilde değerlendirmesidir (McDowell, 2010). Bu durum bir nevi öznel değerlendirmeyi içermekte ve öznel iyi oluşu ifade etmektedir. Farklı bir ifade ile yaşam doyumu bireyin yaşamını bilişsel ve duygusal olarak değerlendirmesidir (Diener, 1984). Yaşam doyumu hayatın belli bir alanı ile sınırlı değildir. Hayatın bütününü olumlu veya olumsuz olarak algılama ile ilgilidir. İnsanın çalıştı̆̆ işinten memnun olması hayatından memnun olduğu sonuçunu çıkarmaz. Yaşam memnuniyeti bireyin bütün yaşamı kapsar (Veenhoven, 1996). Bu açıdan baktığımızda yaşam doyumu bireyin kendi belirlediği değişkenlere göre yaşamını değerlendirmesidir (Dost, 2007). Bu değişkenler ise iş, aile, boş zaman, sağlık, para, benlik ve bireyin yakın çevresidir (Diener ve Lucas, 1999). Yaşam doyumu; ülkenin refah düzeyi, sağlık sektörünün iyi olması, nitelikli eğitim ve olanaklarıyla yakın ilişkilidir. Bireylere bu olanaklar sağlanarak yaşam memnuniyetlerini yükseltilmesi gerekmektedir. İnsanların memnuniyeti artınca daha mutlu olacaklardır. Böylelikle toplumla daha uyumlu, daha üretken insanlar ortaya çıkaracaktır (Seligman ve Csikszentmihalyi, 2000).

Özel eğitim alanı diğer öğretmenlik alanlarına göre daha zor ve daha fazla fedakarlık isteyen bir alandır (Girgin ve Baysal, 2005). Bu alanda çalışan öğretmenlerde yıpranma daha fazla görülmektedir (Brunsting, Sreckovic ve Lane, 2014). Alayazınına baktığımızda Aydemir, Diken, Yıkmış, Aksoy ve Özokçu, (2015), Casteel (2018), Işıktaş (2016), Yılmaz ve Üredi (2018) ve Karabaş ve Çiftçi, (2019) yaptıkları araştırmalar bulunmaktadır. Bu araştırmalar genellikle devlet kurumlarındaki özel eğitim okullarında çalışan öğretmenlerin mesleki tükenmişlik ile yaşama 
doyumlarını incelemişlerdir. Alanyazınında ÖERM'lerde çalışan öğretmenlerin mesleki tükenmişlik ile yaşam doyumları arasındaki ilişkiyi inceleyen bir araştırmaya rastlanmamıştır. ÖERM'lerde çalışan öğretmenlerin mesleki tükenmişlikleri ve yaşam doyumlarını incelemek önemlidir. Çünkü öğretmenlerdeki mesleki tükenmişlik doğal olarak öğrencileri ve öğretmenin kendisini olumsuz yönde etkileyacektir. Ayrıca yaşam doyum düzeyi bireyin tüm yaşamını etkileyen bir değişken olarak bilinmektedir. Bireyin yaşam doyumu yüksek olursa dolaylı olarak kişinin mesleğini de olumlu yönde etkilemesi muhtemeldir. Bu sebeple bu araştırmada ÖERM'lerde çalışan öğretmenlerin mesleki tükenmişlik ile yaşam doyumları düzeyleri belirlenerek olası olumsuz durumları gidermek için gereken çözüm önerileri geliştirmek amaçlanmıştır. Geliştirilen bu önerilerle öğretmenlerin mesleklerini nitelikli bir şekilde yapmaları sağlanacaktır. Bu amaçla bu araştırmada ÖERM'lerde çalışan öğretmenlerin mesleki tükenmişlik ile yaşam doyum düzeyleri çeşitli değişkenler açısından incelenmesi ve mesleki tükenmişlik ile yaşam doyum arasındaki ilişkiyi incelemeyi amaçlamıştır. Bu sebeple aşağıdaki sorulara cevaplar aranmıştır:

1. ÖERM'lerde çalışan öğretmenlerin mesleki tükenmişlik ile yaşam doyumları ne düzeydedir?

2. ÖERM'lerde çalışan öğretmenlerin mesleki tükenmişlik ile yaşam doyumları cinsiyet, ücret, iş arkadaşlarında destek görme ve idarecilerden destek görme değişkeni açısından anlamlı bir farklılık göstermekte midir?

3. ÖERM'lerde çalışan öğretmenlerin mesleki tükenmişlik düzeyleri ile yaşam doyum düzeyleri arasında bir ilişki var mıdır?

\section{Yöntem}

\section{Araştırma Modeli}

Bu araştırma ÖERM'lerde çalışan öğretmenlerin mesleki tükenmişlik ile yaşam doyum düzeyleri çeşitli değişkenler açısından incelenmesi ve mesleki tükenmişlik ile yaşam doyumu arasındaki ilişkiyi incelemeyi amaçladığı için İlişkisel tarama modeli olarak düzenlenmiş ve tarama modeli ile birlikte kullanılmıştır. Tarama modeli Akgün, Büyüköztürk, 
Demirel, Karadeniz, Kılıç ve Çakmak'a (2013) göre bir grubun belli özelliğini tespit etmek amacıyla gerçekleştirilen araştırmalara denir. Bu modelde büyük bir grubun bir konu ile görüşlerini belirlenmesi için grubu temsil edecek evrende örneklem alınır. Bu örneklem üzerinden araştırılan konunun bir fotoğrafı çekilir. İlişkisel tarama modeli ise iki ya da daha çok sayıdaki değişken arasında birlikte değişim varlığını ve/veya derecesini belirlemeyi amaçlayan araştırma modelidir (Karasar, 2013).

\section{Çalışma Grubu}

Bu araştırmanın katılımcıları 2018-2019 yılı eğitim-öğretim yılı içerisinde Edirne ve istanbul illerinde (Edirne ilinden üç ve İstanbul ilinden yedi) 10 ÖERM'de çalışan toplam 175 öğretmendir. Katılımcılara ait demografik bilgiler Tablo 1'de sunulmuştur.

Tablo 1. Araştırmaya katılan öğretmenlerin demografik bilgileri

\begin{tabular}{lcclcc}
\hline \multicolumn{1}{c}{ Cinsiyet } & $\mathbf{N}$ & $\mathbf{\%}$ & İdareciler Destek Görme & $\mathbf{N}$ & $\mathbf{\%}$ \\
\hline Kadın & 62 & 35.4 & Evet & 108 & 61.7 \\
Erkek & 113 & 64.6 & Hayır & 67 & 38.3 \\
Toplam & 175 & 100 & Toplam & 175 & 100.0 \\
\hline İş Arkadaşlarından & Destek & & Ücretten Memnun olma & & \\
\multicolumn{2}{c}{ Görme } \\
\cline { 3 - 6 } & 129 & 73.7 & Evet & 30 & 17.1 \\
Evet & 46 & 26.3 & Hayır & 145 & 82.9 \\
Hayır & 175 & 100.0 & Toplam & 175 & 100.0 \\
Toplam & & & & & \\
\hline
\end{tabular}

Tablo 1'de görüldüğü gibi araştırmaya toplam 175 öğretmen katılmıştır. Katılanların 62'si (\%35,4) erkek, 113'ü $(64,6)$ kadındır. İş arkadaşlarından 129'u (\%73,7) destek görmekte, 46'i (\%26,3) destek görmemektedir. İdareciler destek görme değişkeni açısından 108'i $(\% 61,7)$ destek görmekte, 67'si $(\% 38,3)$ destek görmemektedir. Aldı̆̆ 1 ücretten memnun olma değişkeni açısından 30'u $(\% 17,1)$ aldığı ücretten memnun ve 145 'i $(\% 82,9)$ aldığ

\section{Veri Toplama Araçları}

Kişsel Bilgi Formu: Çalışmada katılımcıların demografik özellikleri hakkında veri toplamak için araştırmacı tarafından kişisel bilgi formu 
hazırlanmıştır. Kişisel bilgi formunda katılımcıların cinsiyeti, aldığı ücretten memnun olma, iş arkadaşlarında destek görme ve idarecilerden destek görme değişkenleri bulunmaktadır.

Öğretmen Mesleki Tükenmişlik ölçeği: Bu araştırmada Ölçeği Kaner, Şekercioğlu ve Yellice (2008) tarafından geliştirilmiş Öğretmen Mesleki Tükenmişlik ölçeği kullanılmıştır. Ölçek likert tipi 5'li, dört alt boyuttan ve yirmialtı maddeden oluşmaktadır. Ölçek alt boyutları ise "Mesleki Tükenmişlik", "Öğrencilere Yabancllaşma", "Fiziksel ve Duygusal Tükenmişlik" ve "Meslektaşlarına ve Yöneticilere Yabancılaşmadır". Ölçeğin Cronbach alfa iç tutarlılık katsayısı ölçeğin tümü için 0.92, alt boyutları için öğretmenlik mesleğine yönelik tükenmişlik 0.90 , öğrencilere yabancılaşma 0.87 , duygusal tükenmişlik, 0.86 ve meslektaşlarına ve yöneticilere yabancılaşma $0.80^{\prime}$ dir.

Yaşam Doyumu Ölçeği: Yaşam Doyumu Ölçeği, Diener, Emmons, Larsen ve Griffin (1985) tarafından geliştirilmiş Dağlı ve Baysal (2016) tarafından Türkçeye uyarlanıp geçerlilik güvenirlilik çalışması yapımıştır. Ölçek orijinalinde beşli likert tipi ve tek boyutludur. Geçerlilik-güvenirlilik çalışması sonucunda yine benzer şekilde beş maddeden, tek boyutlu ve beşli likert tipi şeklinde oluşmuştur. Ölçeğin Cronbach Alpha sayısı 0,88 ve test- tekrar test güvenirliği ise 0,97 olarak bulunmuştur.

\section{Verilerin Toplanması ve Analizi}

Verilerin toplanması için araştırmacı tarafından ÖERM'lere ziyaretlerde bulunulmuştur. Öğretmenlerle yüz yüze görüşerek çalışmanın amacı anlatılmıştır. Araştırmaya katılmaya gönüllü olan öğretmenlere ölçeği nasıl dolduracağı anlatılmıştır. Toplam 240 ölçek dağıtılmış ve 193 ölçek toplanabilmiştir. Toplanan ölçekler incelendiğinde 175 ölçeğin doğru olarak dolduruldu görülmüş ve verilerin analiz 175 ölçek üzerinde gerçekleştirilmiştir. Verilerin normallik testi yapılmıştır. Yapılan test sonucunda basıklık ve çarpıklık değerlerine bakılmıştır. Verilerin basıklık ve çarpıklık değerleri +1.5 -1.5 değerleri arasında ise normal dağılım gösterdiği kabul edilmiştir (Tabachnick ve Fidell, 2013). Normallik testi sonucun da hem mesleki tükenmişlik hem de yaşam doyumu verilerin 
normal dağılım gösterdiği belirlenmiştir. Bu sebeple verilerin analizinde T-Testi kullanılmıştır. Mesleki Tükenmişlik ve Yaşam doyumu arasındaki ilişkiyi incelemek için ise pearson korelasyon analizi uygulanmıştır.

\section{Bulgular}

$\mathrm{Bu}$ bölümde öğretmenlerin mesleki tükenmişlik ve yaşam doyumları cinsiyet, aldıkları ücreti yeterli görme, iş arkadaşlarında destek görme ve idarecilerden destek görme değişkenleri açısından analizleri ve mesleki tükenmişlik ve yaşam doyumu arasındaki ilişki verilerinin analizi sunulacaktır.

Tablo 2. Öğretmen mesleki tükenmişlik ölçeğine ilişkin betimsel istatistik

\begin{tabular}{ccccc}
\hline Ölçek & $\mathrm{N}$ & $\mathrm{m}$ & $\overline{\mathrm{x}}$ & $\mathrm{Sd}$ \\
\hline Öğretmen Mesleki Tükenmişlik Ölçeği & 175 & 26 & 4.17 & 0.67 \\
\hline
\end{tabular}

Tablo 2'de görüldüğü gibi araştırmaya toplam 175 öğretmen katılmıştır. Ölçeğin toplam madde sayısı 26, ölçek aritmetik ortalaması 4.17 ve sd'si 0.67 'dir.

Tablo 3. Öğretmenlerin mesleki tükenmişlik düzeylerinin cinsiyet değişkeni açısından T-testi sonuçlarn

\begin{tabular}{lccccccc}
\hline Ölçek & Cinsiyet & $\boldsymbol{N}$ & $\boldsymbol{x}^{-}$ & $\mathrm{SD}$ & $\mathbf{t}$ & $\mathbf{d f}$ & $\mathbf{p}$ \\
\hline Mesleki tükenmişlik & Erkek & 62 & 3.73 & .62 & -7.28 & 173.00 & .000 \\
& Kadın & 113 & 4.41 & .57 & -7.10 & 116.96 & .000 \\
Mesleğe İlişkin & Erkek & 62 & 3.29 & .75 & -6.39 & 173.00 & .000 \\
Tükenmişlik & Kadın & 113 & 4.16 & .92 & -6.80 & 149.19 & .000 \\
Öğgrencilere Yabancılaşma- & Erkek & 62 & 3.96 & .68 & -10.52 & 173.00 & .000 \\
Öğrencilere Duyarsızlaşma & Kadın & 113 & 4.81 & .39 & -9.10 & 84.37 & .000 \\
Fiziksel ve Duygusal Tü- & Erkek & 62 & 4.00 & .72 & -2.58 & 173.00 & .011 \\
kenmişlik & Kadın & 113 & 4.34 & .88 & -2.74 & 148.55 & .007 \\
Meslektaşlara ve Yöneticilere & Erkek & 62 & 3.66 & .90 & -5.25 & 173.00 & .000 \\
Yabancllaşma-Meslektaşlara & Kadın & 113 & 4.31 & .71 & -4.90 & 103.28 & .000 \\
Yöneticilere & & & & & & & \\
Duyarsızlaşma & & & & & & & \\
\hline
\end{tabular}


Tablo 3'de görüldüğü gibi öğretmenlerin mesleki tükenmişlik düzeyleri genel ölçek bulgularına göre cinsiyet değişkeni açısından anlamlı farklılık $(\mathrm{t}=, 000 ; \mathrm{p}<0,05)$ gözlenmektedir. Ölçek alt boyutlarına bakıldığında ise, mesleğe ilişkin tükenmişlik $(t=, 000 ; p<0,05)$, öğrencilere yabancılaşma-öğrencilere duyarsızlaşma $(t=, 000 ; p<0,05)$, fiziksel ve duygusal tükenmişlik $(t=, 011 ; \mathrm{p}<0,05)$ ve meslektaşlara ve yöneticilere yabancılaşma-meslektaşlara ve yöneticilere duyarsızlaşma $(t=, 000 ; p<0,05)$ alt boyutlarında anlamlı farklılık gözlenmiştir. Ölçek genel puanında kadın öğretmenlerin (Kadın:=4,41; Erkek:=3,73) lehine anlamlı farklılık gözlenmiştir. Ölçek alt boyutlarının ise mesleğe ilişkin tükenmişlik (kadın:=4,16; erkek:=3,29), öğrencilere yabancilaşma-öğrencilere duyarsızlaşma (kadın:=4,81; erkek:=3,96), fiziksel ve duygusal tükenmişlik (kadın: $=4,34$; erkek: $=4,00$ ) ve meslektaşlara ve yöneticilere yabancılaşmameslektaşlara ve yöneticilere duyarsızlaşma (kadın: $=4,31$; erkek:=3,66) alt boyutlarında da kadın öğretmenlerin lehine anlamlı farklılık gözlenmiştir.

Tablo 4. Öğretmenlerin mesleki tükenmişlik düzeylerinin aldığı ücretten memnun olma değişkeni açısından T-Testi sonuçları

\begin{tabular}{|c|c|c|c|c|c|c|c|}
\hline Ölçek & Ücret & $N$ & $x^{-}$ & $S D$ & $\mathrm{t}$ & $\mathrm{df}$ & $\mathrm{p}$ \\
\hline \multirow{2}{*}{ Mesleki tükenmişlik } & Evet & 30 & 4.21 & .63 & .35 & 173.00 & .726 \\
\hline & Hayır & 145 & 4.17 & .68 & .37 & 44.24 & .713 \\
\hline \multirow{2}{*}{$\begin{array}{l}\text { Mesleğe İlişkin } \\
\text { Tükenmişlik }\end{array}$} & Evet & 30 & 3.77 & .83 & -.55 & 173.00 & .585 \\
\hline & Hayır & 145 & 3.87 & .98 & -.61 & 47.54 & .544 \\
\hline \multirow{2}{*}{$\begin{array}{l}\text { Öğgrencilere Yabancilaşma- } \\
\text { Öğrencilere Duyarsızlaşma }\end{array}$} & Evet & 30 & 4.38 & .61 & -1.17 & 173.00 & .244 \\
\hline & Hayır & 145 & 4.53 & .66 & -1.23 & 44.35 & .224 \\
\hline \multirow{2}{*}{$\begin{array}{l}\text { Fiziksel ve Duygusal Tü- } \\
\text { kenmişlik }\end{array}$} & Evet & 30 & 4.55 & .57 & 2.35 & 17.00 & .020 \\
\hline & Hayır & 145 & 4.16 & .87 & 3.08 & 60.98 & .003 \\
\hline Meslektaşlara ve Yöneticilere & Evet & 30 & 4.13 & 1.12 & .36 & 173.00 & .722 \\
\hline $\begin{array}{l}\text { Yabancılaşma-Meslektaşlara } \\
\text { ve Yöneticilere } \\
\text { Duyarsizlaşma }\end{array}$ & Hayır & 145 & 4.07 & .77 & .28 & 34.97 & .780 \\
\hline
\end{tabular}

Tablo 4'de görüldüğü gibi öğretmenlerin mesleki tükenmişlik düzeyleri genel ölçek bulgularına göre aldığı ücretten memnun olma değişkeni açısından anlamlı farklılık ( $t=, 726 ; p>0,05)$ gözlenmemiştir. Ölçek alt boyutlarına bakıldığında ise, mesleğe ilişkin tükenmişlik ( $t=, 585$; $\mathrm{p}>0,05)$, öğrencilere yabancılaşma-öğrencilere duyarsızlaşma $(t=, 244$; 
p>0,05) ve meslektaşlara ve yöneticilere yabancllaşma-meslektaşlara ve yöneticilere duyarsızlaşma $(t=, 722 ; p>0,05)$ anlamlı farklılık gözlenmemiştir. Ölçek alt boyutlarından fiziksel ve duygusal tükenmişlik ( $t=, 020$; $\mathrm{p}<0,05)$ anlamlı farklılık gözlenmiştir. Fiziksel ve duygusal tükenmişlik (Evet:= 4,55; Hayır:= 4,16) alt boyutunda aldı̆̆ ücreti yeterli bulan öğretmenlerden yana anlamlı farklılık gözlenmiştir.

Tablo 5. Öğretmenlerin mesleki tükenmişlik düzeylerinin iş arkadaşlarından destek görme değişkeni açısından t-Testi sonuçları

\begin{tabular}{|c|c|c|c|c|c|c|c|}
\hline Ölçek & & $N$ & $x^{-}$ & $S D$ & $\mathbf{T}$ & df & p \\
\hline \multirow{2}{*}{ Mesleki tükenmişlik } & Evet & 129 & 4.28 & .58 & 3.57 & 173.00 & .000 \\
\hline & Hayır & 46 & 3.88 & .82 & 3.04 & 61.75 & .003 \\
\hline \multirow{2}{*}{$\begin{array}{l}\text { Mesleğe İlişkin } \\
\text { Tükenmişlik }\end{array}$} & Evet & 129 & 3.97 & .91 & 2.66 & 173.00 & .009 \\
\hline & Hayır & 46 & 3.54 & 1.02 & 2.52 & 72.44 & .014 \\
\hline \multirow{2}{*}{$\begin{array}{l}\text { Öğrencilere Yabancılaşma-Öğrencil€ } \\
\text { Duyarsızlaşma }\end{array}$} & Evet & 129 & 4.61 & .53 & 3.63 & 173.00 & .000 \\
\hline & Hayır & 46 & 4.22 & .85 & 2.95 & 58.24 & .005 \\
\hline \multirow{2}{*}{ Fiziksel ve Duygusal Tükenmişlik } & Evet & 129 & 4.32 & .81 & 2.54 & 173.00 & .012 \\
\hline & Hayır & 46 & 3.96 & .89 & 2.43 & 73.25 & .018 \\
\hline \multirow{2}{*}{$\begin{array}{l}\text { Meslektaşlara ve Yöneticilere } \\
\text { Yabancılaşma-Meslektaşlara ve } \\
\text { Yöneticilere Duyarsızlaşma }\end{array}$} & Evet & 129 & 4.19 & .6 & 2.98 & $17 ., 00$ & .003 \\
\hline & Hayır & 46 & 3.77 & .96 & 67,. & 66.23 & .010 \\
\hline
\end{tabular}

Tablo 5'de görüldüğü gibi öğretmenlerin mesleki tükenmişlik düzeyleri genel ölçek bulgularına göre iş arkadaşlarından destek görme değişkenine açısından anlamlı farklılık $(t=, 000 ; p<0,05)$ gözlenmektedir. Ölçek alt boyutlarına bakıldığında ise, mesleğe ilişkin tükenmişlik ( $t=, 009$; $\mathrm{p}<0,05)$, öğrencilere yabancilaşma-öğrencilere duyarsızlaşma $(\mathrm{t}=, 000$; $p<0,05)$, fiziksel ve duygusal tükenmişlik $(t=, 012 ; p<0,05)$ ve meslektaşlara ve yöneticilere yabancılaşma-meslektaşlara ve yöneticilere duyarsızlaşma $(t=, 003 ; p<0,05)$ anlamlı farklılık gözlenmiştir. Ölçek genel puanında iş arkadaşlarından destek görenlerin (Evet: $=4,28$; hayır: $=3,88$ ) lehine anlamlı farklılık gözlenmiştir. Ölçek alt boyutlarının ise mesleğe ilişkin tükenmişlik (Evet:=3,97;hayır:=3,54), öğrencilere yabancılaşma-öğrencilere duyarsızlaşma (evet:=4,61; hayır:=4,22), fiziksel ve duygusal tükenmişlik (evet:=4,32; hayır:=3,96) ve meslektaşlara ve yöneticilere yabancılaşmameslektaşlara ve yöneticilere duyarsılaşma (evet:=4,19; hayır:=3,77) 
boyutlarında da iş arkadaşlarından destek görenlerin lehine anlamlı farklılık gözlenmiştir.

Tablo 6. Öğretmenlerin mesleki tükenmişlik düzeylerinin yöneticilerden arkadaşlarından destek görme değişkeni açısından t-Testi sonuçları

\begin{tabular}{|c|c|c|c|c|c|c|c|}
\hline Ölçek & & $N$ & $\bar{x}$ & $S D$ & $\mathbf{t}$ & df & $\mathrm{p}$ \\
\hline \multirow{2}{*}{ Mesleki tükenmişlik } & Evet & 108 & 4.42 & .59 & 6.87 & 173 & .000 \\
\hline & Hayır & 67 & 3.78 & .61 & 6.80 & 135.65 & .000 \\
\hline \multirow{2}{*}{$\begin{array}{l}\text { Mesleğe İlişkin } \\
\text { Tükenmişlik }\end{array}$} & Evet & 108 & 4.11 & .80 & 4.81 & 173 & .000 \\
\hline & Hayır & 67 & 3.44 & 1.05 & 4.52 & 112.67 & .000 \\
\hline \multirow{2}{*}{$\begin{array}{l}\text { Öğrencilere } \\
\text { Yabancilaşma-Öğren- } \\
\text { cilere Duyarsızlaşma }\end{array}$} & Evet & 108 & 4.59 & .64 & 2.13 & 173 & .034 \\
\hline & Hayır & 67 & 4.38 & .65 & 2.13 & 139.09 & .035 \\
\hline \multirow{2}{*}{$\begin{array}{l}\text { Fiziksel ve Duygusal Tü- } \\
\text { kenmişlik }\end{array}$} & Evet & 108 & 4.47 & .80 & 5.32 & 173 & .000 \\
\hline & Hayır & 67 & 3.82 & .75 & 5.42 & 147.91 & .000 \\
\hline \multirow{2}{*}{$\begin{array}{l}\text { Meslektaşlara ve Yöneti- } \\
\text { cilere Yabancılaşma- } \\
\text { Meslektaşlara ve Yöneti- } \\
\text { cilere Duyarsızlaşma }\end{array}$} & Evet & 108 & 4.53 & .65 & 12.18 & 173 & .000 \\
\hline & Hayır & 67 & 3.36 & .55 & 12.67 & 157.31 & .000 \\
\hline
\end{tabular}

Tablo 6'da görüldüğü gibi öğretmenlerin mesleki tükenmişlik düzeyleri genel ölçek bulgularına göre yöneticilerden destek görme değişkeni açısından anlamlı farklılık $(\mathrm{t}=, 000 ; \mathrm{p}<0,05)$ gözlenmektedir. Ölçek alt boyutlarına bakıldığında ise, mesleğe ilişkin tükenmişlik ( $t=, 000$; $\mathrm{p}<0,05)$, öğrencilere yabancilaşma-öğrencilere duyarsızlaşma $(\mathrm{t}=, 034$; $\mathrm{p}<0,05)$, fiziksel ve duygusal tükenmişlik $(t=, 000 ; p<0,05)$ ve meslektaşlara ve yöneticilere yabancılaşma-meslektaşlara ve yöneticilere duyarsızlaşma $(t=, 000 ; p<0,05)$ anlamlı farklılık gözlenmiştir. Ölçek genel puanında yöneticilerden destek görenlerin (Evet: $=4,42$; Hayır: $=3,78$ ) lehine anlaml1 farklılık gözlenmiştir. Ölçek alt boyutlarının ise mesleğe ilişkin tükenmişlik (evet:=4,11; hayır:=3,44), öğrencilere yabancılaşma-öğrencilere duyarsızlaşma (evet:=4,59; hayır:=4,38), fiziksel ve duygusal tükenmişlik (evet:=4,47; hayır:=3,82) ve meslektaşlara ve yöneticilere yabancılaşmameslektaşlara ve yöneticilere duyarsılaşma (evet:=4,53; hayır:=3,36) boyutlarında da yöneticilerden destek görenlerin lehine anlamlı farklılık gözlenmiştir. 
Tablo 7. Öğretmenlerin yaşam doyum ölçeğine ilişkin betimsel istatistik sunulmuştur

\begin{tabular}{ccccc}
\hline Ölçek & $\mathbf{N}$ & $\mathbf{m}$ & $\mathbf{x}$ & Sd \\
\hline Yaşam Doyumu Ölçeği & 175 & 5 & 2.83 & 1.09 \\
\hline
\end{tabular}

Tablo 7'de görüldüğü gibi araştırmaya 175 öğretmen katılımıştır. Yaşam doyum ölçeğinin madde sayısı 5, ölçeğin aritmetik ortalaması 2.83 olarak gözlenmiştir ve sd'si 1.09 olarak bulunmuştur.

Tablo 8. Öğretmenlerin yaşam doyum düzeylerini cinsiyet değişkeni açısından T-Testi sonuçları

\begin{tabular}{cccccccc}
\hline Ölçek & Cinsiyet & $\boldsymbol{N}$ & $\overline{\boldsymbol{x}}$ & $\boldsymbol{S D}$ & $\mathbf{t}$ & $\mathbf{d f}$ & $\mathbf{p}$ \\
\hline \multirow{2}{*}{ Yaşam doyumu } & Erkek & 62 & 2.58 & 1.17 & -2.36 & 173.00 & .020 \\
& Kadın & 113 & 2.98 & 1.02 & -2.26 & 112.02 & .025 \\
\hline
\end{tabular}

Tablo 8'de görüldüğü gibi öğretmenlerin yaşam doyum düzeyleri genel ölçek bulgularına göre cinsiyet değişkeni açısından anlamlı farklılık $(t=, 020 ; p<0,05)$ gözlenmektedir. Ölçek genel puanına göre kadın öğretmenlerin (Kadın:=2,98; Erkek:=2,58) lehine anlamlı farklılık gözlenmiştir.

Tablo 9. Öğretmenlerin yaşam doyum düzeylerini aldı̆̆ı ücretten memnun olma değişkeni açısından T-Testi sonuçları

\begin{tabular}{cccccccc}
\hline & Ücret & $N$ & $x^{-}$ & $S D$ & $\mathrm{t}$ & $\mathrm{df}$ & $\mathrm{p}$ \\
\hline \multirow{2}{*}{ Yaşam doyumu } & Evet & 30 & 3.30 & 1.18 & 2.61 & 173.00 & .010 \\
& Hayır & 145 & 2.74 & 1.05 & 2.42 & 39.01 & .020 \\
\hline
\end{tabular}

Tablo 9'da görüldüğü gibi öğretmenlerin yaşam doyum düzeyleri genel ölçek bulguları açısından aldığı ücretten memnun olma değişkeni açısından anlamlı farklılık $(\mathrm{t}=, 010 ; \mathrm{p}<0,05)$ gözlenmiştir. Ölçek genel puanına göre aldığ1 ücretten memnun olan öğretmenlerin (Evet:= 3,30; Hayır:= 2,74) lehine anlamlı farklılık gözlenmiştir.

Tablo 10. Öğretmenlerin yaşam doyum düzeylerini iş arkadaşlarnndan destek görme değişkeni açısından T-Testi sonuçları

\begin{tabular}{clcccccc}
\hline Ölçek & & $\boldsymbol{N}$ & $\boldsymbol{x}$ & SD & $\mathbf{t}$ & $\mathbf{d f}$ & $\mathbf{p}$ \\
\hline \multirow{2}{*}{ Yaşam doyumu } & Evet & 129 & 2.99 & 1.01 & 3.25 & 173.00 & .001 \\
& Hayır & 46 & 2.40 & 1.17 & 3.03 & 70.43 & .003 \\
\hline
\end{tabular}


Tablo 10'da görüldüğü gibi öğretmenlerin yaşam doyum düzeyleri genel ölçek bulgularına göre iş arkadaşlarından destek görme değişkeni açısından anlamlı farklılık $(\mathrm{t}=, 001 ; \mathrm{p}<0,05)$ gözlenmiştir. Ölçek genel puanında iş arkadaşlarından destek gören öğretmenlerin (Evet:=2,99; Hayır:= 2,40) lehine anlamlı farklılık gözlenmiştir.

Tablo 11. Öğretmenlerin yaşam doyum düzeylerini yöneticilerden arkadaşlarından destek görme değişkeni açısından T-Testi sonuçları

\begin{tabular}{clcccccc}
\hline Ölçek & & $\boldsymbol{N}$ & $\boldsymbol{x}$ & $\boldsymbol{S D}$ & $\mathbf{t}$ & $\mathbf{d f}$ & $\mathbf{p}$ \\
\hline \multirow{2}{*}{ Yaşam doyumu } & Evet & 108 & 3.30 & .76 & 8.53 & 173.00 & .000 \\
& Hayır & 67 & 2.09 & 1.13 & 7.80 & 103.13 & .000 \\
\hline
\end{tabular}

Tablo 11'de görüldüğü gibi öğretmenlerin yaşam doyum düzeyleri genel ölçek bulguları göre yöneticilerden destek görme değişkeni açısından anlamlı farklılık $(\mathrm{t}=, 000 ; \mathrm{p}<0,05)$ gözlenmiştir. Ölçek genel puanında yöneticilerden destek gören öğretmenlerin (Evet: =3,30; Hayır:=2,09) lehine anlamlı farklılık gözlenmiştir.

Tablo 12. Öğretmenlerin mesleki tükenmişlik ve yaşam doyum düzeyleri puanı korelasyonlar

\begin{tabular}{lr}
\hline \multicolumn{1}{c}{ Mesleki Tükenmişlik Ve Alt Boyutları } & Yaşam Doyumu \\
\hline Mesleki tükenmişlik & $-.358^{*}$ \\
Mesleğe İlişkin Tükenmişlik & $-.209^{*}$ \\
Öğrencilere Yabancılaşma-Öğrencilere Duyarsızlaşma & $-.191^{*}$ \\
Fiziksel ve Duygusal Tükenmişlik & $-.623^{*}$ \\
$\begin{array}{l}\text { Meslektaşlara ve Yöneticilere Yabancllaşma-Meslektaşlara ve } \\
\text { Yöneticilere Duyarsızlaşma }\end{array}$ & $-.398^{*}$ \\
\hline * $p<.01$ &
\end{tabular}

Tablo 12'de görüldüğü gibi Mesleki Tükenmişlik ölçeği ve ölçek alt boyutları ile yaşam doyumu arasındaki ilişkiyi incelemek için Pearson korelasyon katsayısı hesaplaması yöntemi kullanılmıştır. Analiz sonuçlarına göre hem Mesleki Tükenmişlik ölçeği ve ölçek alt boyutları ile yaşam doyumu arasında negatif yönde anlamlı ilişki gözlenmiştir. Farklı bir ifade ile tükenmiş düzeyi arttıkça yaşam doyumu artmaktadır. 


\section{Tartışma ve Yorum}

$\mathrm{Bu}$ bölümde araştırma sonuçları mesleki tükenmişlik ve yaşam doyum düzeyleri cinsiyetler, aldıkları ücreti yeterli görme, iş arkadaşlarında destek görme ve idarecilerden destek görme değişkenleri ve mesleki tükenmişlik ve yaşam doyumu arasındaki ilişki verilerinin analizi sonuçları tartışılacaktır. Genel olarak araştırma sonuçlarına baktığımızda ÖERM'lerde çalışan öğretmenlerin mesleki tükenmişlik düzeyleri yüksek olduğu gözlenmiştir. Öğretmenlerin mesleki tükenmişlik düzeyleri cinsiyet desiğkeni açısından, kadın öğretmenlerin, is arkadaşlarında destek görenlerin ve yöneticlerden destek gören öğretmenlerde daha yüksek olduğu gözlenmiştir. Aldığı ücretten memnun olma değişkeni açısından, aldığ $\breve{1}$ ücrettten memnun olan ve olmayan öğretmenlerin mesleki tükenmişlik düzeylerinde bir fark gözlenmemiştir. Ancak fiziksel ve duygusal tükenmişlik alt boyutunda aldığı ücretten memnun olan öğretmenlerin mesleki tükenmişlik dzüeylerinin daha yüksek olduğu gözlenmiştir. Öğretmenlerin yaşam doyum düzeylerinin orta düzeyde olduğu gözlenmiştir. Öğretmenlerin yaşam doyum düzeyleri cinsiyet değişkeni açısından kadın öğretmenlerden yana, aldığı ücretten memnun olan öğretmenlerden yana, iş arkadaşlarından destek gören öğretmenlerde daha yüksek düzeyde gözlenmiştir. Özel Eğitim ve Rehabilitasyon merkezlerinde (ÖERM) çalışan öğretmenlerin mesleki tükenmişlik düzeyleri ile yaşam doyumları arasında negatif yönlü ilişki gözlenmiştir.

Araştırma sonuçlarına göre ÖERM'lerde çalışan öğretmenlerin mesleki tükenmişlik düzeyleri yüksek çıkmıştır. Alanyazınına baktığımızda benzer sonuçlar bulunmaktadır. Akıncı (2016) yaptığı araştırmada ÖERM'lerde çalışan öğretmenlerin tükenmişlik düzeylerini devlet okulunda çalışan öğretmenlerden daha yüksek olduğu sonucuna ulaşmıştır. Selbi (2018) yaptığı araştırmada ÖERM'lerde çalışan öğretmenler depresyon stres ve uyku problemleri olduğu sonucuna ulaşmıştır. Korucu (2005) yaptığı araştırmada ÖERM'lerde çalışan öğretmenlerin yoğun çalışma temposu içinde çalıştıklarını ve bu durumunda onları olumsuz olarak etkilediği sonucuna ulaşmıştır. Tüm bu veriler öğretmenlerin tükenmişlik düzeylerini artıran faktörlerdir. Ayrıca Akçamete, Kaner ve Sucuoğlu (1998) göre yetersizliği olan bireylerle çalışan öğretmenlerde tükenmişlik düzeyi daha yüksektir. Bu sebeplerle bu araştırma sonucuna 
göre ÖERM'lerde çalışan öğretmenlerin tükenmişlik düzeylerinin yüksek olduğunu söyleyebiliriz.

Öğretmenlerin mesleki tükenmişlik düzeyleri cinsiyet değişkenine göre erkek öğretmenelere kıyasla kadın öğretmenlerde daha yüksek olduğu gözlenmiştir. Bu sonuç alanyazınında bazı araştırmalarla tutarlılık göstermektedir. Karakoç (2011) yaptığı yöneticlerle yaptığ1 araştırmada ÖERM'lerde çalışan kadın yöneticilerin erkek yöneticilerden nispeten daha fazla tükenmişlik yaşadıkları sonucuna ulaşmıştır. Karahan ve Balat'ın (2011) yılında özel eğitim okullarında çalışan kadın öğretmenlerin kişisel başarı alt boyutunda erkek öğretmenlere oranla daha fazla tükenmişlik yaşadıklarını gözlemlemiştir. Buna karşın Akıncı (2016) yaptığ1 araştırmada ÖERM'lerde çalışan kadın öğretmenler ile erkek öğretmenler arasında anlamlı bir fark gözlenmemiştir. Nichols ve Sosnowsky (2002) yaptığı araştırmada özel eğitim okullarında çalışan öğretmenlerin cinsiyet değişkeni açısından tükenmişlik düzeylerinde bir fark gözlememiştir. ÖERM'lerde çalışan kadın öğretmenlerin tükenmişlik düzeylerinin yüksek olmasının sebebini kadınların daha hasass ve daha duyarlı olmalarına bağlanabilir.

Öğretmenlerin Mesleki Tükenmişlik düzeyleri aldığı ücretten memnun olma değişkeni açısından genel ölçek puanında anlamlı bir farklılık göstermemiştir. Sadece ölçek alt boyutlarından fiziksel ve duygusal tükenmişlik alt boyutunda aldığ farklılık gözlenmiştir. Alanyazınına baktığımızda ücretin iş doyumunu olumlu yönde etkilediğini ifade eden çalışmalar bulunmaktadır. Akman (2017) göre ücret değişkeni ÖERM'lerde çalışanların iş doyumunu olumlu yönde etkilemektedir. Öztürk (2015) ise tükenmişliğe etki eden faktörler arasında düşük ücret olduğunu ifade etmiştir. Boe, Bobbitt ve Cook (1997) göre yeterli ücret almayan öğretmenler özel eğitim alanında çalışmayı bırakmaktadırlar. Buna karşın Akçamete, Kaner ve Sucuoğlu (2001) ve Oruç (2007) yaptıkları araştırmada ücret değişkeni ile özel eğitim öğretmenlerinin mesleki tükenmişlik düzeyleri arasında anlamlı bir ilişki gözlememişlerdir. $\mathrm{Bu}$ araştırmada mesleki tükenmişlik düzeylerinin aldığı ücretten memnun olma değişkeni açısından genel ölçek puanında anlamlı bir farklılık gözlenmemesi ve sadece ölçek alt boyutlarından fiziksel ve duygusal tükenmişlik alt boyutunda aldığ ücretten memnun 
olanlardan yana tükenmişliğin yüksek olarak gözlenmesi bu öğretmenlerin kişilik özelliklerinden kaynaklanıyor olabilir. Başka bir deyişle öğretmeler aldıkları ücreti düşünmeyip sadece mesleklerini layığıyla yapmayı düşünmüş olabilirler.

Öğretmenlerin mesleki tükenmişlik düzeyleri genel ölçek bulgularına ve ölçek tüm alt boyutlarına göre iş arkadaşlarından destek görenlerden yana anlamlı farklılık gözlenmiştir. alanyazınına baktığımızda iş arkadaşlarından destek görenlerin daha fazla tükenmişlik duygusu yaşadıkları gözlenmiştir. Aksoy (2007), Girgin ve Baysal (2005) ve Zabel ve Zabel, (2002) yaptıkları araştırmada iş arkadaşlarından destek görme ile mesleki tükenmişlik arasında anlamlı bir ilişki gözlemişlerdir. Yavuz ve Özgür (2016) yaptıkları araştırmada ölçek alt boyutlarından meslektaşlara ve yöneticilere yabancılaşma-meslektaşlara ve yöneticilere duyarsızlaşma alt boyutunda meslektaşlarından destek görmeyen öğretmenlerden yana anlamlı farklılık gözlenmiştir. Bu araştırmada meslektaşlarından destek görmesine rağmen tükenmişlik düzeyinin yüksek olması ve bunun yanında destek görmeyenlerde tükenmişliğin düşük olması kişilik yapılarından ve ailevi sorunlardan kaynaklanıyor olabilir. Akçamete, Kaner ve Sucuoglu (2001) göre bazı kişiler kişilik yapılarından (öfke, huzursuzluk, sabırsızlık, aşırı titizlik) kaynaklı olarak doğal olarak tükenmişlik duygusu yaşamaya daha yatkındır. Bunun yanında Torun (1997) ve Buick ve Thomas (2001) göre ise tükenmişliği aile yapısı gibi, boşanmış veya hiç evlenmeme vb. değişkenler etkilemektedir. Bu açılardan baktığımızda bu araştırmada çalışma arkadaşlarından destek görmesine ragmen öğretmnelerin mesleki tükenmişlik düzeyinin yüksek olmasının sebebi bu değişkenler olabilir. Farklı bir ifade ile bireyin mesleki tükenmişliğini sadece okul yaşantısı ile değil tüm yaşantısıyla birlikte değerlendirmek mesleki tükenmişliği daha iyi anlamamıza yardımcı olacaktır.

Öğretmenlerin mesleki tükenmişlik düzeyleri genel ölçek bulgularına ve ölçek tüm alt boyutlarına göre yöneticilerden destek görenlerden yana anlamlı farklılık gözlenmiştir. Alanyazınına baktığımızda yöneticilerden destek görmenin yetersizliği olan çocuklarla çalışan öğretmenlerin tükenmişlik düzeyini etkileyen faktör olduğunu görmekteyiz. Işık (2014) göre ÖERM'lerde yöneticilerin çalışanlarla işbirliği yapmaması, sorunlara çözüm üretmemeleri, yöneticilerin hata odaklı denetim yapması, başarıyı 
görmezden gelmesi ve çalışanlarla empati kuramaması öğretmenlerin kurumdan ve öğretmenlikten soğumasına neden olmaktadır. Akman (2017) ve Lawrenson ve McKinnon (1982) ise yöneticilerin öğretmenlere destek olması çalışanların motivasyonunu artırıcı yönde katkı sağlamaktadır. Zabel ve Zabel'e (2001) yaptıkları araştırmada özel eğitim öğretmenleri idarecilerden destek görmeyenlerde tükenmişlik duygusunu yüksek olarak gözlemişlerdir. Bu araştırmada idarecilerden destek görmelerine rağmen öğretmenlerin tükenmişlik düzeylerinin yüksek olmasının gerekçesi üst paragrafta tartışıldığı gibi öğretmenlerin kişisel ve ailevi özelliklerinden kaynaklı olabilir.

ÖERM'lerde çalışan öğretmenlerin yaşam doyum düzeyleri orta düzeyde çıkmıştır. Alanyazınına baktığımızda bu bulguları destekleyecek araştırma sonuçlarına rastlamaktayız. Demirel (2014) birinci kademe ve ikinci kademe öğretmenleriyle yaptığı araştırmada öğretmenlerin yaşam doyum düzeylerini orta düzeyde olduğunu gözlemiştir. Karabaş ve Çiftçi, (2019) özel eğitim öğretmenleriyle yaptıkları çalışmada öğretmenlerin yaşam doyum düzeylerini orta düzeyde olduğunu gözlemişlerdir. Bu araştırma sonuçlarına baktığımızda hem yaşam koşullarının zorlukları hem de özel eğitim alanın diğer öğretmenlik alanlarına göre zor olmasından kaynaklı olarak ÖERM'lerde çalışan öğretmenlerin yaşam doyum düzeylerinin yüksek olmadığını söyleyebiliriz.

ÖERM'lerde çalışan öğretmenlerin yaşam doyum düzeyleri cinsiyet değişkeni açısından erkek öğretmenlere kıyasla kadın öğretmenlerde daha yüksek olduğu gözlenmiştir. Alanyazınına baktığımızda bu araştırma sonuçlarıyla paralel araştırma sonuçlarına rastlanmıştır. Aydemir, Diken, Yıkmış, Aksoy, Özokçu (2015), Demirel (2014) ve Karabaş ve Çiftçi, (2019) özel eğitim öğretmenleriyle yaptıkları çalışmada kadın öğretmenlerde yaşam doyumunu yüksek bulmuşlardır. Avşaroğlu, Deniz ve Kahraman (2005) Teknik öğretmenlerin yaşam doyumu düzeylerini incelediği araştırmasında kadın öğretmenlerin yaşam doyum düzeylerini daha yüksek olduğunu gözlemiştir. Buna karşın Işıktaş (2016) yaptığ araştırmada özel eğitim okullarında çalışan öğretmenlerde cinsiyet değişkeni açısından anlamlı bir farklılık gözlememiştir. Şahin (2008) beden eğitimi öğretmenleriyle yaptığı araştırmada yaşam doyumu ile cinsiyet değişkeni arasında anlamlı bir ilişkiye rastlanmamıştır. Mutham- 
izhselvan ve Kumar (2017) yaptıkları araştırmada ikinci kademe öğretmenlerinde yaşam doyum düzeyleri arasında anlamlı bir farka rastlamamışlardır. Bu araştırmada ÖERM'lerde çalışan öğretmenlerin yaşam doyum düzeyleri cinsiyet değişkeni açısından anlamlı bir farklılık gözlenmesinin nedeni kadınların dünyaya daha pozitif bakmaları ile açıklanabilir. Bunun yanında toplumumuzda öğretmenlik mesleğinin kadınlara daha uygun görülmesiyle de açıklanabilir. Aydemir, Diken, Yıkmış, Aksoy, Özokçu (2015) yaptıkları araştırmada kadın öğretmenlerde yaşam doyum düzeylerinin yüksek olmasını kadınların öğretmenlik mesleğinin daha uygun görülmesiyle açıklanmıştır.

ÖERM'lerde çalışan öğretmenlerin yaşam doyum düzeyleri aldığ1 ücretten memnun olan öğretmenlerden yana anlamlı farklılık gözlenmiştir. Alanyazınına baktığımızda alınan ücretten memnun olma yaşam doyumuna olumlu katkı yaptığını belirten çalışmalar bulunmaktadır. Akman (2017) ÖERM'lerde çalışan öğretmenlerin yaptığı araştırmada çalışılan işten tatmin edici ücret alınması bireyin yaşamına ve psikolojisine olumlu katkı sağladığını ifade etmiştir. Ancak öğretmenin yaptığı işe karşılık yeterli ücret almadığını düşünmesi öğretmeni huzursuz etmektedir. Atmaca (2019) ÖERM'lerde çalışan öğretmenlerle yaptığ1 araştırmada öğretmenler bazen düzenli olarak maaş alamamaları hayatlarını olumsuz etkilemektedir. Çetin'e (2004) göre özel eğitim diğer eğitim alanlarına göre daha zorluklarla dolu bir alandır. Bu sebeple çalışanların kendini tatmin edecek ücretleri almaları gerekmektedir. Bu araştırma sonuçlarına göre ÖERM'lerde çalışan öğretmenlerin yaşam doyum düzeylerine ücret değişkenine göre anlamlı farklılık çıkmasının gerekçesi, çalıştığı işte tatmin edici ücret almak yaşam doyumunu artırıcı bir değişken olarak yorumlanabilir.

ÖERM'lerde çalışan öğretmenlerin yaşam doyum düzeyleri iş arkadaşlarından destek görenlerden yana anlamlı farklılık göstermiştir. Alan yazınına baktığımızda iş arkadaşlarından destek görmenin bireyin yaşamına olumlu katkı sağladığını belirten çeşitli çalışmalar bulunmaktadır. Atmaca (2019) ÖERM'lerde çalışan öğretmenlerle yaptığı araştırmada çalışanların iş arkadaşlarıyla problemler yaşadıklarını bu durumunda kendilerini olumsuz etkilediklerini ifade etmişlerdir. Akman (2017) ÖERM'lerde çalışan öğretmenlerle yaptı̆̆ araştırmada bazı öğret- 
menlerin olumsuz tavırları diğer çalışanları da olumsuz etkileyebilmektedir. Akman (2017) göre "bu özelliklere sahip bireyler, kuruma ve iş arkadaşlarına olumsuz düşünceler besledikleri için hem kendileri mutsuz ve çalışma arkadaşlarını da mutsuz ederek verimliliği ve motivasyonu düşürmektedirler". Bu sonuçlara baktığımızda ÖERM'lerde çalışan öğretmenlerin yaşam doyum düzeylerini belirleyen değişkenlerden biri de çalışma arkadaşlarından destek görmesidir. Çalışma arkadaşlarından destek gören öğretmenlerin yaşam doyum düzeyleri yükselmektedir.

ÖERM'lerde çalışan öğretmenlerin yaşam doyumu yöneticilerden destek görenlerden yana anlamlı farklılık göstermektedir. Alanyazınına baktığımızda yöneticilerin öğretmenlere desteğinin bireyin iş hayatına ve yaşamına olumlu katkı sağladığını belirten çalışmalar bulunmaktadır. Hocalar (2018) yaptığı araştırmada ÖERM'lerde çalışan yöneticilerin yüksek lisans yapması daha bilinçli hareket etmelerine neden olacağını bununda ÖERM'lerde çalışan öğretmenlere olumlu katkı sağlayacağını belirtmektedir. Işık (2014) göre ÖERM'lerde çalışan yöneticilerin öğretmenlerle okuldaki problemler konusunda birlikte çalışmaması ve bu problemlere çözüm üretmemeleri öğretmenlerin kuruma güven duygunu yitirmesine ve işten ayrılmasına neden olabilmektedir. Alanyazına baktığım zaman yaşam doyum alanları içinde bireyin çalıştığı işte bulunmaktadır (Şahin, 2008). Eğer birey çalıştı̆̆ 1 işte mutlu değilse bu durum yaşam doyumunu da olumsuz etkileyecektir. Bu araştırma bulgularına göre ÖERM'lerde çalışan öğretmenlerin yaşam doyum düzeylerini etkileyen değişkenler arasında idarecilerin desteğinin önemli bir rol oynadığını söyleyebiliriz.

ÖERM'lerde çalışan öğretmenlerin mesleki tükenmişlik düzeyleri ile yaşam doyumları arasında nagatif yönlü ilişki gözlenmiştir. Alan yazınına baktığımızda bu araştırma bulgularıyla destekler yönde araştırma sonuçlarına rastlanmaktadır. Aydemir, Diken, Yıkmış, Aksoy, Özokçu (2015), Işıktaş (2016) Karabaş ve Çiftçi, (2019) özel eğitim öğretmenleriyle yaptıkları araştırmalarda tükenmişlik ile yaşam doyumu arasında negatif yönde anlamlı ilişki gözlemlemişlerdir. Ancak Avşaroğlu, Deniz ve Kahraman (2005) teknik lise öğretmenleriyle yaptıkları araştırmada yaşam doyumu ile tükenmişlik ölçeği alt boyutlarından duygusal tükenme ve kişisel başarısızlık arasında negatif yönlü anlamlı bir ilişki bulmuşlardır. Ayrıca yaşam doyumu ile tükenmişlik 
ölçeği alt boyutlarından duyarsızlaşma arasında anlamlı bir ilişki gözlememişlerdir. Şahin (2008) beden eğitimi öğretmenleriyle yaptıkları araştırmada yaşam doyumu ile tükenmişlik ölçeği alt boyutlarından duygusal tükenme arasında negatif yönlü, yaşam doyumu ile kişisel başarı arasında alt boyutunda pozitif yönlü anlamlı bir ilişki bulmuştur. Ancak yaşam doyumu ile tükenmişlik ölçeği alt boyutlarından duyarsızlaşma arasında anlamlı bir ilişki saptanmamıştır.

$\mathrm{Bu}$ araştırmanın belli sınırlılıkları bulunmaktadır. Bu araştırma Edirne ve İstanbul ili ile sınırlıdır. Bu araştırma bu araştırmaya katılan 175 öğretmen ile ve yaşam doyumu ölçeği ve öğretmen mesleki tükenmişlik ölçekleri ile sınırlıdır.

İleriki araştırmalarda ise başka illerde ÖERM'lerde çalışan öğretmenlerle yapılabilir. ÖERM'lerde çalışan öğretmenlerin yaşam doyumu düzeyleri, öz-yeterlilik, mesleki öz-yeterlilik veya iş doyumu gibi değişkenlerle arasındaki ilişki incelenebilir. Benzer şekilde ÖERM’lerde çalışan öğretmenlerin mesleki tükenmişlik düzeyleri öz-yeterlilik, mesleki öz-yeterlilik veya iş doyumu gibi değişkenlerle arasındaki ilişki incelenebilir. Ayrıca hem yaşam doyumu hem de mesleki tükenmişlik düzeylerini derinlemesine incelemek için görüşme yöntemi (karma yöntem) ile birlikte kullanılabilir. ÖERM'lerde çalışan öğretmenlerin yaşam doyum düzeylerini artırmak ve mesleki tükenmişlik düzeylerini azaltmak için ÖERM kurum sahipleri öğretmenlerin ücretlerini arttırabilir, çalışma saatlerini azaltabilir veya öğretmenlerin moralini ve motivasyonunu arttırmak için tüm kurumun katılacağ şekilde piknik, gezi, tiyatro, sinema gibi etkinlikler düzenleyebilir. 
EXTENDED ABSTRACT

\title{
An Investigation on Occupational Burnout Levels and Life Satisfaction of Teachers Working in Special Education and Rehabilitation Centers
}

\author{
Mehmet Yavuz \\ Trakya University
}

Burnout was first described by Freudenberger (1974) as "a state of exhaustion that results from failure, fatigue, loss of energy and power, or unfulfilled desires of a person's internal resources". Burnout syndrome is usually seen in individuals who have to work face to face with people. This syndrome generally consists of three sub-dimensions which are emotional exhaustion, depersonalization and diminished personal success. Teachers working in Special Education and Rehabilitation Centers (SERC) are likely to experience burnout syndrome because they work with individuals with disabilities. Occupational burnout is observed among teachers working in the field of special education due to factors such as working with students with disabilities who have developmental deficiencies, difficulties in the education of these individuals and teachers' not getting occupational satisfaction. In addition to these, teachers stated that they have various problems in SERCs. For example, teachers can keep their expectations from students high or low because of their parents' lack of consciousness and the inspectors conducting inspections are not special educators. Besides, students forget the behaviors that they gained because of long holidays and the classes are not homogeneous. Moreover, teachers also stated that they were very busy (work eight hours a day), had low wages, had a lot of paperwork, had a shortage of educational materials, and worked under poor physical conditions in the institutions. Teachers may also have problems with administrators and parents. In addition, it is known that teachers who are not graduates of special education department working in SERCs have lack of knowledge about preparing and implementing an In- 
dividualized Education Program (IEP), determining and applying appropriate teaching methods, selecting materials, teaching and evaluating new behaviors, and coping with problem behaviors.

There are several factors affecting burnout. One of these factors is life satisfaction. Life satisfaction is an individual's assessment of the quality of his or her life in a holistic framework and internally. It includes a kind of subjective assessment and expresses subjective well-being. In other words, life satisfaction is an individual's evaluation of his or her life cognitively and emotionally. Life satisfaction is not limited to a certain area of life. It is about perceiving life as a whole as positive or negative. The fact that a person is satisfied with his job does not mean that he is satisfied with his life. Life satisfaction covers the whole life of an individual. When considered from this point of view, life satisfaction is an individual's evaluation of his or her life according to the variables determined by him / her. These variables are work, family, leisure time, health, money, personality and immediate circle of the individual. Life satisfaction is closely related to the welfare level of the country, having a good health sector, qualified education and equal opportunities. It is necessary to increase life satisfaction by providing individuals with these opportunities because people will be happier when their satisfaction increases. In this way, they will be more productive and more compatible with society.

To the best of our knowledge, there is no research in the literature examining the relationship between the occupational burnout and life satisfaction of teachers working in SERCs. It is important to examine the occupational burnout and life satisfaction of teachers working in SERCs because burnout in teachers naturally affects both students and themselves negatively. Since the level of life satisfaction is a variable that affects the whole life of the individual, it is possible that if the life satisfaction of the teacher is high, it will indirectly affect the profession positively. For this reason, in this research, it is aimed to investigate the life satisfaction and occupational burnout of teachers working in SERCs and to come up with solutions to cope with possible negative situations. It is believed that these solutions will enable teachers to perform their profession in a more qualified way. For this purpose, it was aimed to investigate the levels of occupational burnout and life satisfaction of teachers working in SERCs in 
terms of various variables and to investigate the relationship between occupational burnout and life satisfaction. Therefore, the answers to the following questions were sought.

1. What is the level of occupational burnout and life satisfaction of teachers working in SERCs?

2. Do the occupational burnout and life satisfaction of teachers working at SERCs show a significant difference in terms of the variables regarding gender, salary, support from colleagues, and support from administrators?

3. Is there a relationship between occupational burnout and life satisfaction levels of teachers working at SERCs?

Since this study aims to investigate the levels of occupational burnout and life satisfaction of teachers working in SERCs in terms of various variables and to investigate the relationship between occupational burnout and life satisfaction, it was designed as a descriptive and correlational research and survey model was used. The participants of the research are 175 people working at 10 of the SERCs in Edirne and Istanbul provinces (three from Edirne province and seven from Istanbul) during the 20182019 academic year. A total of 175 teachers participated in the study. 62 (35.4\%) of the participants were male and 113 (64.6\%) were female. Of the participants, $129(73.7 \%)$ stated that they received support from their colleagues, while 46 (26.3\%) said they did not. In terms of the receiving support from administrators variable, while 108 of the participants $(61.7 \%)$ responded positively, 67 (38.3\%) stated that they did not receive support. As for being content with the salary variable, although 30 of them (17.1\%) were satisfied with their salary, 145 (82.9\%) were not.

In the study, a personal information form was prepared by the researcher to collect data about the demographic characteristics of the participants. In addition, the occupational burnout scale for teachers developed by Kaner, Şekercioğlu and Yellice (2008) and the satisfaction with life scale which was originally developed by Diener, Emmons, Larsen and Griffin (1985) and was later adapted to Turkish by Dağlı and Baysal (2016) were used. The reliability and validity study for the Turkish version was conducted by the same researchers. T-Test and Pearson Correlation analysis were used for data analysis. 
According to the results of the study, occupational burnout levels of the teachers working at SERCs were high. Significant differences were found in the gender variable of the teachers' occupational burnout level in favor of female teachers, those who were supported by their colleagues, and those who were supported by their administrators. There was no significant difference in the satisfaction with the variable regarding the received salary, but a significant difference was detected in the sub-dimension of physical and emotional burnout in favor of the ones who were satisfied with their salary. The life satisfaction levels of the teachers participating in the research were found to be moderate. When concerning the gender variable, there was a significant difference in the life satisfaction levels of the teachers in favor of the female teachers, the teachers who were satisfied with the salary they received, and those who were supported by their colleagues. Moreover, a negative correlation was found between the level of occupational burnout and life satisfaction.

\section{Kaynakça / References}

Akçamete, G., Kaner, S. ve Sucuoglu, B. (1998). Engelli ve engelli olmayan çocuklarla çalışan öğretmenlerin tükenmişlik ve iş doyumu düzeyleri arasındaki ilişkinin karşılaştırmalı olarak incelenmesi. VI. Ergonomi Kongresi. Ankara: Milli Prodüktivite Merkezi Yayınları.

Akçamete, G., Kaner, S. ve Sucuoğlu, B. (2001). Öğretmenlerde tükenmişlik iş doyumu ve kişilik. Ankara: Nobel Yayınevi..

Akgün, A. E., Büyüköztürk, Ş., Demirel, F., Karadeniz, Ş. ve Çakmak, E. (2013). Bilimsel araştırma yöntemleri. Ankara: Pegem Akademi Yayıncilik.

Akın, U. ve Oğuz, E. (2010). Öğretmenlerin işkoliklik ve tükenmişlik düzeylerinin ilişkisi ve çeşitli değişkenler açısından incelenmesi. Kuram ve Uygulamada Ĕ̆itim Yönetimi, 16(3), 309-327.

Akıncı, M. (2016). Özel eğitim kurumlarında (Rehabilitasyon) ve devlet okullarında çalışan öğretmenlerin tükenmişlik düzeyleri. Yayınlanmamış Yüksek Lisans Tezi, Beykent Üniversitesi Sosyal Bilimler Enstitüsü, İstanbul.

Akman, S. (2017). Özel eğitim ve rehabilitasyon kurum çalışanlarının örgütsel sinizm ile iş doyumuna yönelik görüşleri. Yayınlanmamış Yüksek Lisans Tezi, Abant İzzet Baysal Üniversitesi Eğitim Bilimleri Enstitüsü, Bolu. 
Aksoy, S. U. (2007). Eskişehir ili özel eğitim kurumlarında çalışan öğretmenlerin tükenmişlik düzeylerinin değerlendirilmesi. Yayınlanmamış Yüksek Lisans Tezi, Eskişehir Osmangazi Üniversitesi Sağlık Bilimleri Enstitüsü, Eskişehir.

Atmaca, U. (2019). Özel ĕgitim ve rehabilitasyon merkezlerinde çalışan öğretmenlerin işitme kayıplı bireylere verilen destek hizmetlerine ilişkin görüşlerinin incelenmesi. Yayınlanmamış Yüksek Lisans Tezi, Anadolu Üniversitesi Eğitim Bilimleri Enstitüsü, Eskişehir.

Avşaroğlu, S, Deniz, E. M. ve Kahraman, A. (2005). Teknik öğretmenlerde yaşam doyumu, iş doyumu ve mesleki tükenmişlik düzeylerinin incelenmesi. Selçuk Üniversitesi Sosyal Bilimler Enstitüsü Dergisi, 14, 115-129.

Aydemir, H., Diken, İ., K., Yıkmış, A., Aksoy, V. ve Özokçu, O. (2015). Özel eğitim alanında çalışan öğretmenlerin tükenmişlik düzeyleri ve yaşam doyumlarının incelenmesi. Abant İzet Baysal Üniversitesi Ĕ̆itim Fakültesi Dergisi, 15(Special Issue), 68-86.

Boe, E. E., Bobbitt, S. A. ve Cook, L. H. (1997). Whither didst thou go? Retention, reassignment, migration, and attrition of special and general education teachers in national perspective. The Journal of Special Education, 30, 371-389.

Brunsting, N. C., Sreckovic, M. A. ve Lane, K. L. (2014). Special education teacher burnout: a synthesis of research from 1979 to 2013. Education and Treatment of Children, 37(4), 681-711.

Buick, I ve Thomas, M. (2001). Why do middle managers in hotels burn out? International Journal of Contemporary Hospitality Management, 13(6), 304-309.

Casteel, C. L. (2018). The relationship between certification type and burnout, perceived support, job satisfaction, and life satisfaction in special education teachers. Yayınlanmamış doktora tezi. Texas A\&M University-Commerce. ABD.

Çetin, Ç. (2004). Özel eğitim alanında çalışmakta olan farklı meslek grubundaki eğitimcilerin yaşadığı güçlüklerin belirlenmesi. Özel Ĕ̆itim Dergisi, 5(1) 35-46.

Çetin, M. E. ve Şen, S. G. (2017). Özel eğitim ve rehabilitasyon merkezlerinde çalışan öğretmenlerin sorunlarının belirlenmesi. International Journal of Social Science, 59(I), 53-69. 
Dağll, A. ve Baysal, N. (2016). Yaşam doyumu ölçeğinin Türkçe 'ye uyarlanması: geçerlik ve güvenirlik çalışması. Elektronik Sosyal Bilimler Dergisi, 15(59),1250-1262.

Demirel, H. (2014). An investigation of the relationship between job and life satisfaction among teachers. Procedia-Social and Behavioral Sciences $116,4925-4931$

Diener, E. (1984). Subjective well-being. Psychological Buletin, 95 (3), 542-575.

Diener, E. ve Lucas, R. E. (1999). Subjective well-being: Three decades of progress. Psychological Bulletin, 125 (2), 276-303.

Dost, M. T. (2007). Üniversite öğrencilerinin yaşam doyumunun bazı değişkenlere göre incelenmesi. Pamukkale Üniversitesi Ĕ̆itim Fakültesi Dergisi, 2(22), 132-143.

Garden, A. M. (1987). Depersonalisation, a valid dimension of burnout? Human Relations 40,545-60.

Girgin, G. ve Baysal, A. (2005). Zihinsel engelli öğrencilere eğitim veren öğretmenlerin mesleki tükenmişlik düzeyi ve bazı değişkenler (İzmir ömeği). Pamukkale Üniversitesi Ĕ̆itim Fakültesi, 18, 3-15.

Hocalar, H. (2018). Özel eğitim ve rehabilitasyon merkezlerinde yönetim süreçlerinin işleyişinin yönetici ve öğretmen görüşlerine göre değerlendirilmesi (Bursa ili örneği). Yayınlanmmış Yüksek Lisans Tezi, Trakya Üniversitesi Sosyal Bilimler Enstitüsü, Edirne.

Işık, M. (2014). Özel eğitim uygulama merkezi ve iş uygulama merkezinde çalı̧an zihin engelliler sınıf öğretmenlerinin yaşadığı sorunlar. Atatürk Üniversitesi Eğitim Bilimleri Enstitüsü. Erzurum.

Işıktaş, S. (2016). Özel eğitim öğretmenlerinin tükenmişlik ve yaşam doyumlarına ilişkin görüşlerinin incelenmesi. Turkish Studies, 11(19) 461-476.

Jackson, S. E., Schwab, R. L. ve Schuler, R. S. (1986). Toward an understanding of the burnout phenemeo. Journal of Applied Psychology, 11, 615-27.

Kaner, S., Şekercioğlu, G. ve Yellice, B. (2008). Öğretmen mesleki tükenmişlik ölçeği geliştirme çalışması. Eğitimde ve Psikolojide Ölçme ve Değerlendirme Kongresi.

Karabaş, M. ve Çiftçi, S. (2019). Özel eğitim alanında görev yapan sınıf öğretmenlerinin tükenmişlik ve yaşam doyumlarının incelenmesi. Uluslararası Ĕ̆itim Bilimleri Dergisi, 6(19), 128-149. 
Karahan, Ş. ve Balat, G. (2011). Özel eğitim okullarında çalışan eğitimcilerin özyeterlik algılarının ve tükenmişlik düzeylerinin incelenmesi. Pamukkale Üniversitesi Ĕ̆itim Fakültesi, 29, 1-14.

Karakoç, B. (2011). Özel eğitim ve rehabilitasyon merkezlerinde çalışan yöneticilerin tükenmişlik düzeyleri ile algıladıkları rol çatışması arasındaki ilişkinin karşılaştırılması. Uşak Üniversitesi Sosyal Bilimler Enstitüsü, Uşak.

Karasar, N. (2013). Bilimsel araştırma yöntemi. Ankara: Nobel Yayın Dağıtım.

Karasu, T. ve Mutlu, Y. (2014). Öğretmenlerin perspektifinden özel eğitimde yaşanan sorunlar ve çözüm önerileri: Muş il örneği. Muş Alparslan Ünïversitesi Sosyal Bilimler Dergisi, 2(1), 47-66.

Korucu, N. (2005). Türkiye’de özel eğitim ve rehabilitasyon hizmeti veren kurumların karşılaştığı güçlüklerin analizi: Kurum sahipleri, müdür, öğretmen ve aileler açısından. Yayımlanmamış Yüksek Lisans Tezi. Selçuk Üniversitesi Sosyal Bilimler Enstitüsü. Konya.

Maslach, C. ve Jackson, S. E. (1981). The measurement of experienced burnout. Journal of Occupational Behaviour, 2, 99-113

Maslach, C. (1993). Burnout: A multidimensional perspective. W.B. Schaufeli, C. Maslach, ve T. Marek (edit.). Professional burnout: Recent development in theory and research (s. 19-32). NY: Taylor \& Francis.

Maslach, C., Schaufeli, W. B. ve Leiter, M. P. (2001). Job Burnout. Annual Reviews of Psychology, 52, 397-422.

Mcdowell, I. (2010). Measures of self-perceived well-being. Journal Of Psychosomatic Research, 69,69-79.

Muthamizhselvan, M. ve Kumar, L. (2017). Life satisfaction of secondary school teachers. International Journal of Multidisciplinary Research and Development, 4(9), 55-58.

Nichols, A. S. ve Sosnowsky, F. L. (2002). Burnout among special education teachers in self-contained cross-categorical classrooms. Teacher Education and Special Education, 25(1), 71-86.

Oruç, S. (2007). Özel eğitim alanında çalışan öğretmenlerin tükenmişlik düzeylerinin bazı değişkenler açısından incelenmesi (Adana ili örneği). Yayımlanmamış yüksek lisans tezi, Çukurova Üniversitesi, Adana.

Öztürk, D. (2015). Eğitim örğütlerinde okul kültürü ve tükenmişlik düzeyi arasındaki ilişki. Yayınlanmamış Yükseklisans Tezi, Yeditepe Üniversitesi, İstanbul. 
Schwarzer, R., Schmitz, G. S. ve Tang, C. (2000). Teacher burnout in Hong Kong and Germany: A cross cultural valididation of Maslach Burnout Inventory. Anxiety, Stres, and Coping, 13, 309-326.

Selbi, H. H. (2018). Özel eğitim ve rehabilitasyon, hastanelerde çalışan fizyoterapistler ile aktif çalışan öğretmenlerde yaşam kalitesi, ağrn ve depresyon değgrlendirilmesi. Yayınlanmmış Yüksek Lisans Tezi, Gaziantep Üniversitesi Sağlık Bilimleri Enstitüsü, Gaziantep.

Seligman, M. E. P. ve Csikszentmihalyi, M. (2000). Positive psychology: An introduction. American Psychologist, 55, 5-14. doi/10.1037/0003066X.55.1.51997.

Sucuoğlu, B. ve Kuloğlu, N. (1996). Özürlü çocuklarla çalışan öğretmenlerde tükenmişliğin değerlendirilmesi. Türk Psikoloji Dergisi, 11(36) 44-60.

Şahin, Ş. (2008). Beden eğitimi öğretmenlerinin tükenmişlik ve yaşam doyumu düzeyleri. Yayımlanmamış Yüksek Lisans Tezi, Mersin Üniversitesi, Eğitim Bilimleri Enstitüsü, Mersin.

Tabachnick, B. G. ve Fidell, L.S. (2013). Using Multivariate Statistics. Boston: Pearson.

Torun, A. (1997). Stres ve tükenmişlik, Suna Tevrüz, (Edit) Endüstri ve örgüt psikolojisi, (s, 43-53). İstanbul: Türk Psikologlar Derneği ve Kalite Derneği Ortak Yayını.

Tuğrul, B. ve Çelik, E. (2002). Normal çocuklarla çalışan anaokulu öğretmenlerinde tükenmişlik. Pamukkale Üniversitesi Eğitim Fakültesi Dergisi, 2, (12), 1-11.

Tümkaya, S. (1996). Öğretmenlerdeki tükenmişlik, görülen psikolojik belirtiler ve başa çıkma davranışları. Yayınlanmamış Doktora.Tezi, Çukurova Üniversitesi. Adana.

Ufuk, A. (2019). Özel eğitim ve rehabilitasyon merkezlerinde çalışan öğretmenlerin işitme kayıpl bireylere verilen destek hizmetlerine iliş̧kin görüşlerinin incelenmesi. Yayınlanmmış Yüksek Lisans Tezi, Anadolu Üniversitesi Eğitim Bilimleri Enstitüsü, Eskisehir.

Veenhoven, R. (1996). Happy life-expectancy: a comprehensive measure of quality-oflife in nations. Social Indicators Research, 39,1-58.

Yavuz, M. ve Özgür, H. (2016). Otistik spektrum bozukluğu olan öğrencilerle çalışan öğretmenlerin mesleki tükenmişlik düzeylerinin incelenmesi. Trakya Üniversitesi Sosyal Bilimler Dergisi, 18(2), 47-67. 
Yılmaz, M. ve Üredi, L. (2018). Alan değişikliğiyle özel eğitim okullarında çalışan sınıf öğretmenleri ile özel eğitim öğretmenlerinin mesleki doyum düzeylerinin incelenmesi: (Mersin ili örneği). Uluslararası Ĕ̆itim Bilimleri Dergisi, 5(15), 59-79.

Zabel, R. H. ve Zabel, M. K. (2001). Revisiting burnout among special education teachers: Do age, experience, and preparation still matter? Teacher Education and Special Education, 24(2), 128-139.

\section{Kaynakça Bilgisi / Citation Information}

Yavuz, M. (2019). Özel eğitim ve rehabilitasyon merkezlerinde çalışan öğretmenlerin mesleki tükenmişlik düzeyleri ve yaşam doyumlarının incelenmesi . OPUS-Uluslararası Toplum Araştırmaları Dergisi, 13(19), 527-556. DOI: 10.26466/opus.601008 